\title{
The Beginnings of Mechanization in the Algonquin Park Forest Industry
}

A Snapshot of the First Experiments with Mechanized Equipment

A

lthough the forest industry in the Algonquin area had seen steady change and evolution since its start in the early 1800s, the pace of change really began to accelerate with the advent of mechanization starting around the mid 1920s.

In the early years, logging activities in Algonquin were strongly determined by the seasons. Winter was the time that the trees were felled, first by axes and later by the newly introduced crosscut saws. The snow and cold was necessary for the logs to be skidded from the stump to the landings and from there to be pulled by horse and sleigh to the river or lakeside. The spring was the time that logs were driven down rivers and floated down lakes to their final destination. The very early years saw square timber cribs taken to ships in Quebec City and in later years the sending of sawlogs to various sawmills in the Algonquin, Muskoka and Ottawa Valley areas. In the sawlog days, the summer was the time to run the sawmills and saw the logs into lumber while the

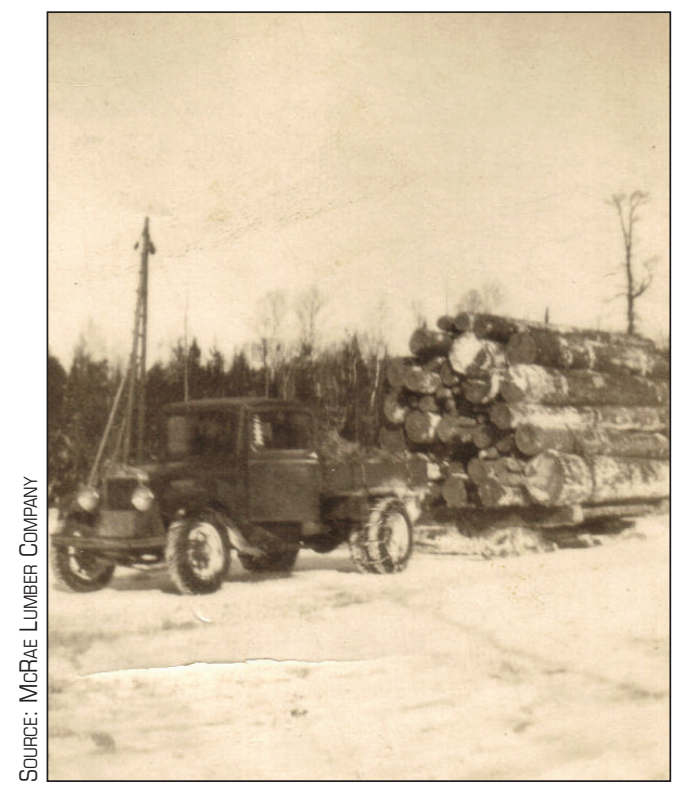

Early truck and sleigh. fall saw the building of the bush camps and tote roads in preparation for another winter in the bush.

The 1920s were the start of an evolution in the forest, which begins with an industry dependent on the strength and muscle of men and horses and changes into our current industry that is heavily reliant on machines and technology.

This reliance on men and horses was one of the primary drivers for change and evolution in the forest industry. Bush camps cutting sawlogs were busy places and required large numbers of men and horses to get the logs out of the forest. A typical camp in the Algonquin area could have about 100 men and 30 horses. A camp of this size required considerable planning and continuous effort to supply them. Food had to be good and plentiful and it wasn't uncommon for the cook to be one of the highest paid men in the camp. In addition to the hot meals, cooks would often bake 30 loaves of bread and 48 pies per day for one camp as well as a variety of other pastries, all cooked on wood stoves. Horses also needed to be fed well, and the typical rations for a large workhorse could consist of one bushel of oats per team (two horses) per day as well as 34-50 pounds of hay per horse per day. The costs were significant to run bush camps and this was one factor that led to the hope that with increased mechanization would come decreased costs.

Logging with horses was a difficult and demanding job at the best of times. It was often very dangerous, especially drawing fully loaded sleighs down steep hills. And it was slow work, horses could only pull sleighs at a walking pace and required rest. The prospect of mechanization with the ability to increase production, while making the bush a safer place, was also a strong factor in many companies willing to take their chances with these new developments.

In the bush horses were used for three main tasks; these were: skidding the logs from the stump to the landing, providing the power to hoist the logs onto a sleigh by using a gin pole or jammer and pulling the loaded sleighs to the lakeside or train siding.

The first of these tasks where mechanization began to be used as a substitute was in pulling the sleighs. Early trials involved the use of tractors to pull the loaded sleighs across the frozen lakes. An example of these early tractors was the Ford Fordson tractor, which could pull multiple loaded sleighs. The exploration for a substitute for the horse in the pulling of the sleighs continued in earnest during the 1930s with the introduction of trucks. Trucks could pull multiple sleighs and quickly. Gary Cannon, a long-time bush foreman for the McRae Lumber Company commented that: "I remember when McRae bought their first trucks. They bought two Mack trucks in about 1935. The first trucks we used were for pulling sleighs. They were 2.5 and 3 tons. They'd take the dump box off the back of the truck and put a little box on, about 8 foot square, and fill it up with sand and put ice chains on it. And that was your hauling for the winter, pulling the sleighs over iced roads." Trucks continued to dominate the hauling of logs and as they became more powerful the loads became greater. Once the trucks became heavy and strong enough the logs began to be loaded directly on the back of the truck.

Although horses began to be substituted for machinery in the hauling of loaded sleighs, it took more time to find suitable replacements for providing power to load the logs onto the sleighs. Gin poles and jammers were a simple system of using a single upright pole (gin pole) or two poles in an A frame (jammer) as a tower with a cable suspended from the top that went through a pulley. The cable could be raised and lowered as required by a team of horses 
pulling the other end of the cable. This system was in use for many years, but was dangerous work that required at least three men and a team of horses. An example of an early mechanized substitution was the use of power jammers. These were two large " $\mathrm{A}$ " frame towers with cables suspended between them that were powered by a diesel engine. This system could pile logs higher and faster than traditional horsepowered jammers. However, the real change to the loading of logs came with the advent of hydraulic-powered loaders in the late 1950s and early 1960s. These machines were generally mounted on trucks and allowed a single operator to load the logs onto the trucks. The early versions of these machines still bear a significant resemblance to the modern loaders used in the forest today.

The final and most difficult task of replacing the horse was the skidding of the logs from the stump to the landing. Horses were extremely versatile and could easily navigate the terrain and move around remaining trees as required. However, after the Second World War the number of trucks in use around the province greatly diminished the number of horses available as well as the supply of harnesses, collars and other essential equipment. Another factor was the bottleneck in productivity that started to occur as a result of the introduction of the chainsaw. The efficiency of chainsaws took a while to adjust to as traditional skidding with horses couldn't keep pace with felling trees by chainsaw. There were many different machines that were experimented with, but for a long time nothing seemed to work that well. Some of the machines that were tried were Blue

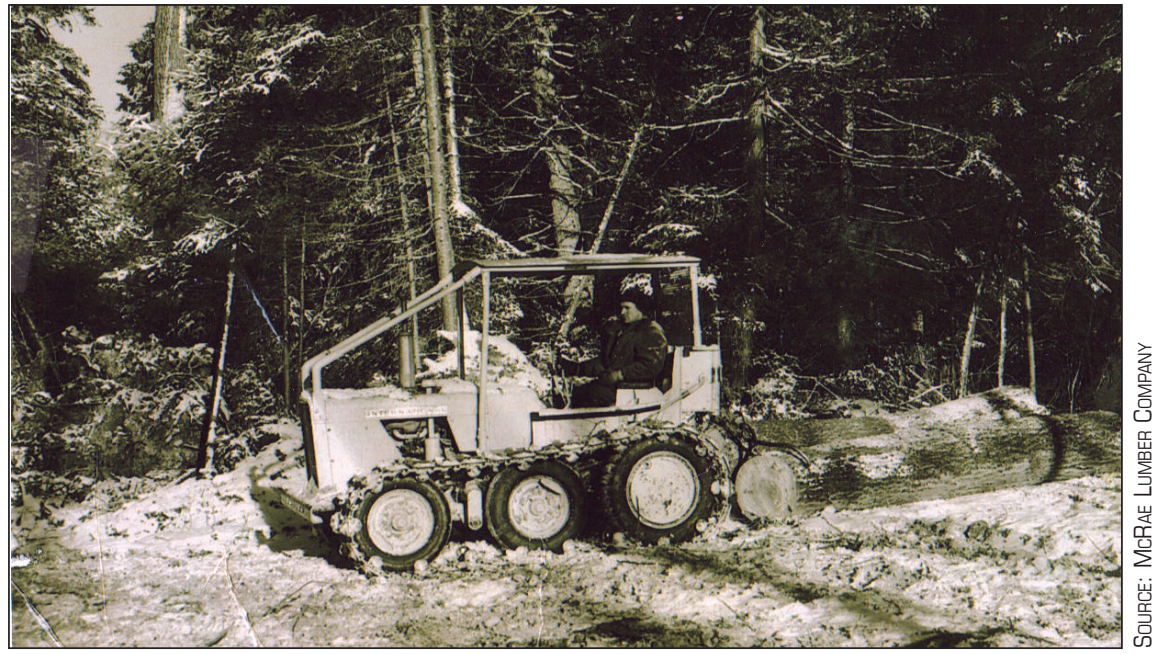

International crawler tractor

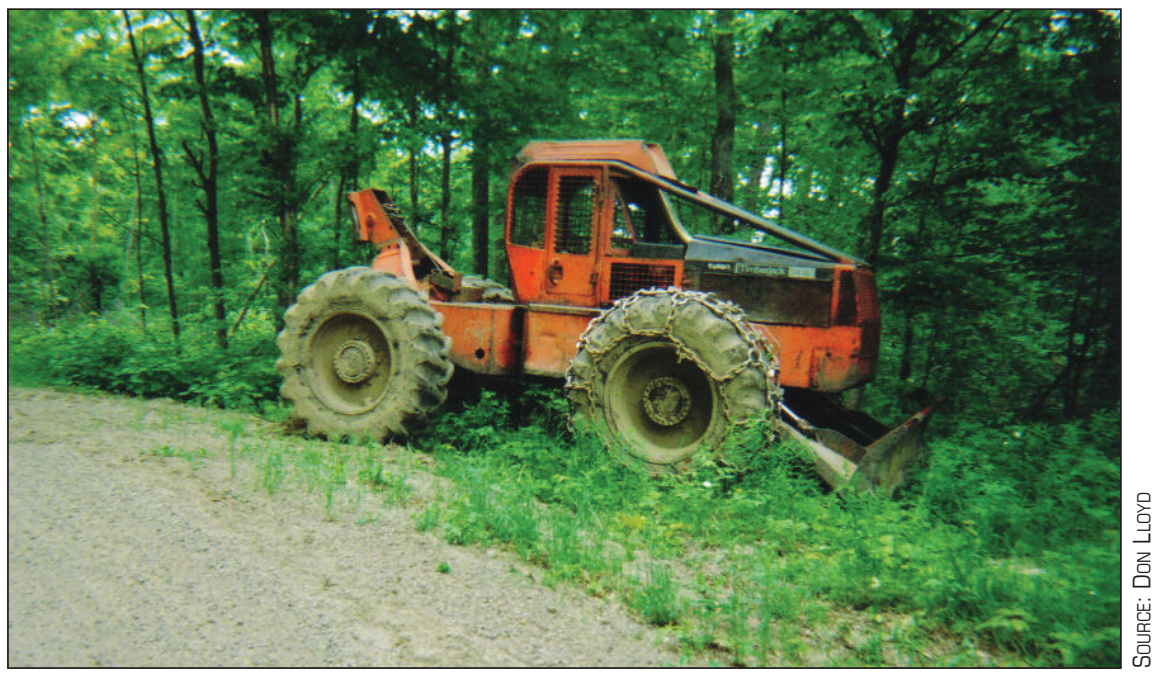

Timberjack Skidder

Ox skidder tractors, John Deere crawler tractors and International crawler tractors. The solution was finally found when the Department of Lands and Forests and the Industry worked together to develop a prototype articu-

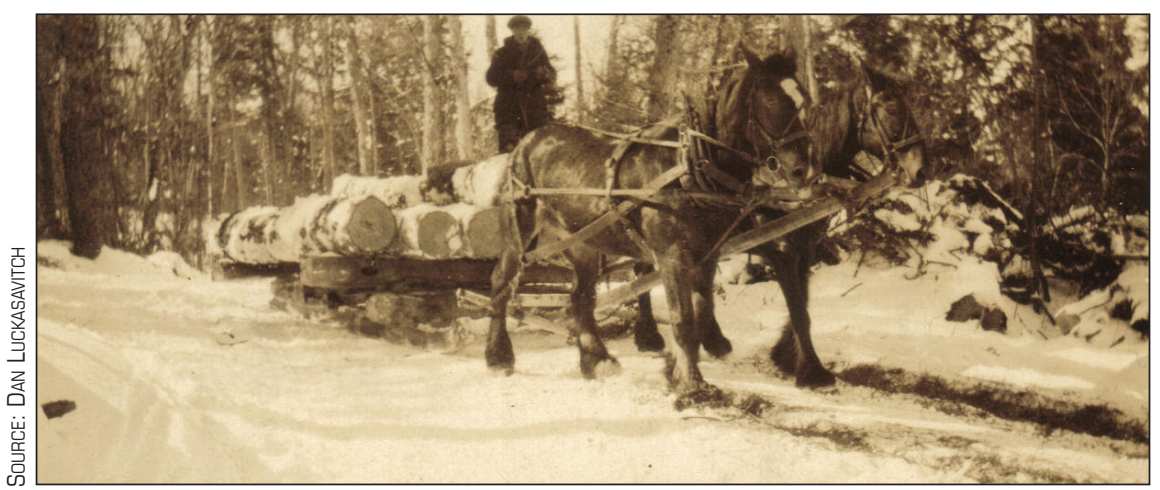

Team of horses with loaded sleigh lated skidder, a vehicle that was hinged at the centre and steered by powerful hydraulic arms. The Timberjack was created by Bob Simmons, Wes McGill and Vern King of Woodstock, Ontario in 1960. Its small turning radius gave it good maneuverability, and a winch, operating through an arched fairlead, gave great pulling power. This machine was an instant success and sold worldwide.

Excerpted from Algonquin Harvest The History of the McRae Lumber Company

Jamie McRae

McRae Lumber Company Whitney, Ontario 


\section{Gaining a perspective on world forestry}

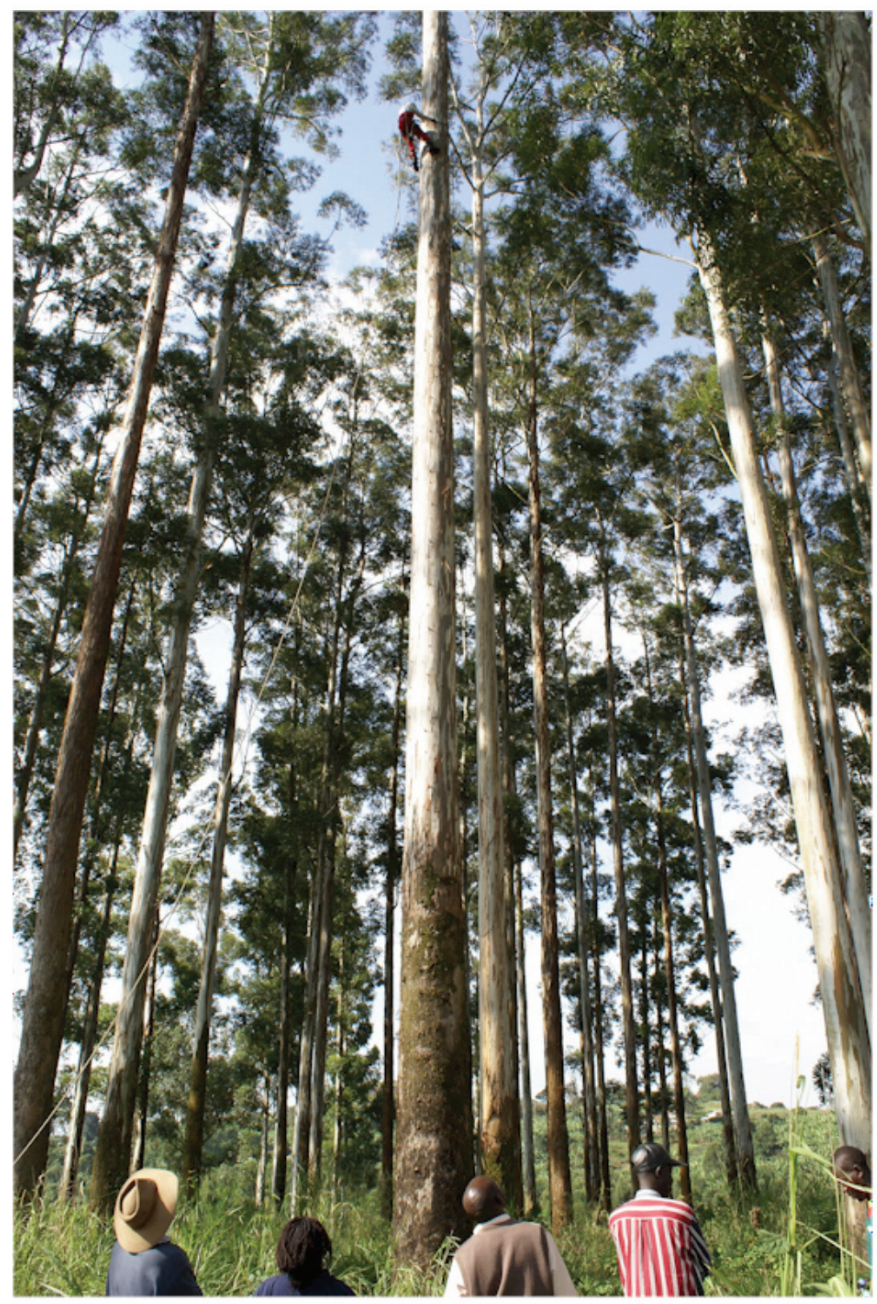

The Commonwealth Forestry

Association is the world's leading professional forestry association focused on international forestry. We:

- Publish world-class science in our peer-reviewed forestry journal, the International Forestry Review.

- Facilitate networking of professional members and organisations and exchange of knowledge via our quarterly newsletter, website, Facebook page and Twitter feed.

- Encourage professional excellence and promote career development using a range of awards, such as the Queen's Award for Forestry, the Young Forester Award and the Young Scientist Research Award.

- Carry out a range of specific projects in the field that have been identified by our membership.

- Promote capacity building by helping to organise training courses, workshops, and conferences.

We are also the home to the secretariat for the Standing Committee on Commonwealth Forests, which is comprised of representatives of all of the forest departments from throughout the Commonwealth. The committee provides a unified voice on forestry matters to governments and international meetings and organises the Commonwealth Forestry Conference, an event which takes place every four years.

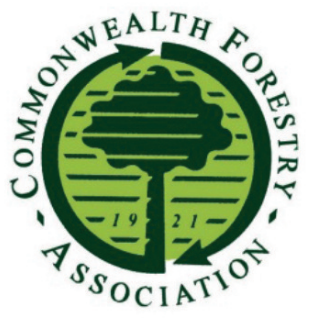

If you join us you'll be supporting future generations of foresters who work on our behalf to manage the environment of trees and forests. Membership is open to all including citizens of non-Commonwealth countries and Commonwealth countries.

Find out more at www.cfa-international.org 